\title{
Impact of Monetary and Macroeconomic Factors on Wheat Prices in Pakistan: Implications for Food Security
}

\author{
Khalid Mushtaq*, Abdul Ghafoor ${ }^{* *}$ Abedullah ${ }^{* * *}$, and \\ Farhan Ahmad****
}

\begin{abstract}
This paper attempts to evaluate the impact of monetary and macroeconomic factors on real wheat prices in Pakistan for the period 1976-2010, using Johansen's co-integration approach. The Augmented Dickey-Fuller test reveals that all the variables used are first-difference stationary, except the trade openness indicator, which is second-difference stationary. There is also a longrun equilibrium relationship among these variables. The results indicate that real money supply, openness of the economy, and the real exchange rate have a significant effect on real wheat prices in the long run. The impulse response function shows that a trade openness shock impacted wheat prices to some extent and that it took three to four years for prices to become stable, following the shock. The findings of the study suggest that the policy thrust should focus on increasing wheat supply in the country by enhancing production or by liberalizing trade. Efforts should also be directed toward stabilizing the value of the Pakistani rupee against foreign currencies, especially the US dollar.
\end{abstract}

Keywords: Wheat prices, co-integration, Pakistan.

JEL Classification: E00, E31.

\section{Introduction}

Pakistan's economy has exhibited a low food-inflation environment over the last several years (single-digit inflation rate) with a sharp pickup during the last three years (Government of Pakistan, 2010). Several internal and external factors have contributed to the recent

\footnotetext{
* Assistant Professor, Department of Agricultural Economics, University of Agriculture, Faisalabad, Pakistan.

** Assistant Professor (TTS), Department of Marketing and Agribusiness, University of Agriculture, Faisalabad, Pakistan.

*** Assistant Professor, Department of Environmental and Resource Economics, University of Agriculture, Faisalabad, Pakistan.

Postgraduate Student, Department of Agricultural Economics, University of Agriculture, Faisalabad, Pakistan.
} 
pickup in food inflation in Pakistan. These factors include: (i) an economic recovery resulting in a rise in the levels of income with a consequential surge in domestic demand, (ii) the continued pass-through effect of the previous rise in international oil prices, and (iii) a sharp pickup in the international prices of essential commodities. A major factor in the rise in inflation is the continuously upward adjustment of administered prices, such as the support prices of wheat. Because of the importance of wheat, successive governments have intervened heavily in wheat markets, procuring wheat at administratively set prices to support farmers' incomes, and subsidizing wheat sales to flour mills or directly to consumers with the objective of stabilizing prices at levels affordable to consumers (Niaz, 1995). Recently, the government increased the price of wheat to stop its illegal leakage from the country. This could have direct implications for food security in the country because wheat is the staple food of a majority of the population.

The high volatility of food prices is of concern to the public and policymakers because such price movements deter increased agricultural productivity and tend to intensify inflationary pressures. Food price volatility also increases the uncertainty faced by farmers and agribusiness firms. In particular, prices are considered a true indicator of resource allocation and, as such, price volatility affects farmers' investment decisions, with serious ramifications for the land under cultivation, debt, farm incomes, and productivity. The shocks to money supply, exchange rates, and trade policies have significant impacts on food prices, real incomes, and per capita domestic food production (Kargbo, 2005).

This study aims to empirically estimate the impact of monetary and macroeconomic factors on wheat crop prices in Pakistan. The paper is organized as follows: Section 2 reviews related studies on food prices, Section 3 presents an empirical framework, Section 4 discusses the empirical results obtained, and Section 5 concludes the study.

\section{Review of the Literature}

The impact of monetary and macroeconomic factors on the agricultural sector, particularly the pricing of agricultural products, has received considerable attention in recent international research. However, investigating the impact of these variables on agricultural prices is a relatively new research area in Pakistan, and the studies available in this area are limited. A review of the existing literature reveals that the 
exchange rate, interest rate, and level of money supply are key monetary variables, whereas the major macroeconomic variables are import/export trade policy instruments.

Barnet et al. (1983) investigate the role of increased money supply in causing a rise in nominal agricultural prices, and finds that agricultural price increases were at the heart of the 1970s inflation. Jabara and Schwartz (1987) show the relationship between agricultural prices and the exchange rate, concluding that the exchange rate affects the price of agricultural commodities. Orden and Fackler (1989) determine the effect of monetary policy and other macroeconomic shocks on the price of agricultural products. Taylor and Spriggs (1989) study the importance of monetary and macroeconomic variables on Canadian agricultural prices, finding that agricultural prices are more responsive to these variables in the short run. Similar findings are obtained by Robertson and Orden (1990) and Lapp and Smith (1992). Sephton (1992) models the link between commodity prices and exchange rates, and finds that currency depreciation Grangercauses commodity price inflation. He also suggests that macro-events have had important effects on commodity markets in Canada. Dorfman and Lastrapes (1996) find that agricultural prices (crops and livestock) increase in the short run as a result of positive money supply shocks.

Khan and Qasim (1996) reveal that greater monetary expansion has caused inflation in Pakistan. Husain and Mahmood (1998) also find a unidirectional relationship between money and prices in Pakistan. Kargbo (2000) examines the impact of monetary and macroeconomic factors on real food prices (RFPs) in eastern and southern Africa. The empirical results show that changes in domestic food production, coupled with income, trade, exchange rate, and monetary policies, have had a significant impact on real food prices with wide implications for food availability and food security in the region. Hyder and Shah (2004) find that the exchange rate has had a moderate effect on wholesale and consumer prices in Pakistan. Akbari and Rankaduwa (2005) indicate that the foreign price level of imports, money supply, and domestic output level are statistically significant determinants of the general price level whereas the exchange rate is a statistically insignificant determinant. Awokuse (2005) examines the dynamic relationship between monetary policy variables and agricultural prices, finding that the exchange rate affects agricultural prices. Cho et al. (2005) explore the linkage between changes in macroeconomic variables (real exchange rate and inflation rate) and changes in relative agricultural prices and show that long-term changes in the real exchange rate have a significant negative correlation 
with long-term changes in relative agricultural prices. Kaabia et al. (2005) analyzes the impact of changes in monetary policy and the exchange rate on agricultural prices. Their results indicate that, while changes in macroeconomic variables affect agricultural prices, the reverse does not hold. Kargbo (2005) studies the impact of monetary and macroeconomic factors on food prices and finds that trade, the exchange rate, and monetary policy reforms have a significant impact on food prices and domestic agricultural production. Khan and Schimmelpfennig (2006) and Qayyum (2006) find a significant relationship between money supply and food inflation. Finally, Asfaha and Jooste (2007) investigate the short- and long-run impacts of monetary policy changes on relative agricultural prices in South Africa, and indicate the existence of a long-run relationship between agricultural prices, exchange rate, and money supply.

\section{Empirical Framework}

\subsection{Data and Variable Specifications}

We use annual time series data in logarithmic form for the period 1976-2010, related to real wheat prices (RWP) (Rs/40 kg), real money supply (RMS) $\left(\mathrm{M}_{2}\right.$, Rs million), real per capita income (Rs/person), real exchange rate (RER) (Rs/US\$), per capita domestic wheat production (tons per million persons), and an indicator for trade openness (TO) (Rs million). ${ }^{1}$ Our data is derived from various issues of the Pakistan Economic Survey, the Food and Agriculture Organization (FAO)'s statistical database, and the Handbook of Statistics on Pakistan's economy.

The wholesale price of wheat in Lahore is used as a proxy for nominal wheat prices and then transformed into real wheat prices using the wholesale price index (WPI) by setting 2000/01 = 100 as the base year. Real money supply and real per capita income is calculated using the gross domestic product (GDP) deflator by setting 2000/01 $=100$ as the base year. The RER is calculated by the formula

$$
\operatorname{RER}=\mathrm{e} \times \mathrm{p} / \mathrm{p}^{*}
$$

where RER is the real exchange rate, $\mathrm{p}$ is the price level of the home country, $\mathrm{p}^{*}$ is the price level in a foreign country, and e is the nominal exchange rate between the currencies of the foreign and home country,

${ }^{1}$ We know that Pakistan's agriculture sector has undergone structural transformation during the last 15-20 years and annual time series data does not depict ST dynamics. 
expressed as the number of foreign currency units per home currency units (Ellis, 2001). Here, we use the wholesale price of wheat in Lahore as a proxy for the price level in Pakistan and the CIF international price of wheat to measure $\mathrm{p}^{*}$. We convert this into rupees by multiplying it by the nominal exchange rate (Rs/US\$). The TO indicator is calculated as the ratio of the sum of the value of total exports and imports over the country's GDP (Kargbo, 2005). It is then converted into real terms using the GDP deflator $(2000 / 01=100$ as the base year $)$.

\subsection{Model Specifications}

RWPs are assumed to be a function of the real money supply (RMS), real per capita income (Y), the RER, per capita domestic food production (DP), and the TO indicator. Thus, the general form of this function $^{2}$ is specified in log form as follows:

In RWP $=\alpha_{0}+\beta_{1}$ RMS $+\beta_{2}$ In $Y+\beta_{3}$ In RER $-\beta_{4}$ In DP $-\beta_{5}$ In TO $+\mu_{\mathrm{t}}$

Here, $\mu_{\mathrm{t}}$ is assumed to be an identically, independently, and normally distributed (IID) error term with zero mean and constant variance. We expect a positive relationship between money supply and wheat prices since an increase in money supply causes the demand for wheat to increase, and this causes an increase in wheat prices. We expect real per capita income to have a positive or no significant impact on wheat prices, because higher income is an incentive for households to spend more on food or shift to luxuries. ${ }^{3}$ If they spend more on food, food prices are likely to surge; if they move toward luxuries, food prices are likely to remain unaffected. The RER is expected to carry a positive sign. Since increase in the RER means that our currency is depreciating resulting in increased exports and lowered imports. The resulting impact on food prices will be positive. Increased domestic production means increased supply and this will result in lowered food prices. Thus, the per capita domestic food production variable is expected to carry a negative sign. The TO indicator is expected to have a negative impact on wheat prices. Since the opening up of an economy to international trade may result in increased imports, thus lowering food prices.

\footnotetext{
${ }^{2}$ The specification of Equation 1 in log form may not be free from the problem of serial correlation.

${ }^{3}$ The literature supported the argument that households in LDCs spend major part of their income on food and Pakistan is no exception in this regard.
} 


\subsection{Estimation Procedure}

We begin by testing for the presence of unit roots in the individual time series of each model using the Augmented Dickey-Fuller (ADF) test (Dickey \& Fuller, 1981) both with and without a deterministic trend. The number of lags in the ADF equation is chosen to ensure that serial correlation is absent using the Breusch-Godfrey statistic (Greene, 2000, p. 541).

An ADF equation is required to estimate the following by ordinary least squares (OLS).

$\Delta Y_{t}=\alpha_{3}+\beta_{3} t+\left(\phi_{3}-1\right) Y_{t-1}+\sum_{i=1}^{k} \theta_{i} \Delta Y_{t-i}+u_{t}$

$Y_{t}$ is the series under investigation, $t$ is a time trend, ${ }^{4}$ and $u_{t}$ refers to white noise residuals.

We do not know how many lagged values of the dependent variable to include on the right-hand side of Equation 2. There are several approaches to this, but we use the Lagrange multiplier test (Holden \& Perman, 1994, p. 62).

If two series are integrated of the same order, Johansen's (1988) procedure can be used to test for the long-run relationship between them. The procedure is based on a maximum likelihood estimation of the vector error correction model:

$\Delta \mathrm{z}_{\mathrm{t}}=\delta+\Gamma_{1} \Delta \mathrm{z}_{\mathrm{t}-1}+\Gamma_{2} \Delta \mathrm{z}_{\mathrm{t}-2}+\square+\Gamma_{\mathrm{p}-1} \Delta \mathrm{z}_{\mathrm{t}-\mathrm{p}+1}+\pi \mathrm{z}_{\mathrm{t}-\mathrm{p}}+\Psi \mathrm{x}_{\mathrm{t}}+\mathrm{u}_{\mathrm{t}}$

$z_{t}$ is a vector of $\mathrm{I}(1)$ endogenous variables, $\Delta z_{t}=z_{t}-z_{t-1}, x_{t}$ is a vector of $\mathrm{I}(0)$ exogenous variables. In this case $z_{t}=\left[R W P_{t}, R M S_{t}, Y_{t}, T O_{t}, R E R_{t}\right]$ and $x_{t}=\left[D P_{t}\right]$. Further, in Equation $3, \pi$ and $\Gamma_{i}$ are $(\mathrm{n} \times \mathrm{n})$ matrices of parameters with $\Gamma_{i}=-\left(I-A_{1}-A_{2}-\ldots-A_{i}\right),(i=1, \ldots, k-1)$, and $\pi=I-\pi_{1}$ $-\pi_{2}-\ldots-\pi_{k}$. This specification provides information about the short-run and long-run adjustments to changes in $z_{t}$ through estimates of $\hat{\Gamma}_{i}$ and $\hat{\pi}$, respectively. The term $\Pi X_{t-p}$ provides information about the long-run equilibrium relationship between the variables in $z_{t}$. Information about

\footnotetext{
${ }^{4}$ The rationale for having a trend variable in the model is that as most of the series are trended overtime. So it is important to test the series for unit root having a stochastic trend against the alternative of trend stationary.
} 
the number of co-integrating relationships among the variables in $z_{t}$ is given by the rank of the $\pi$-matrix: if $\pi$ is of reduced rank, the model is subject to a unit root; if $0<r<n$, where $r$ is the rank of $\pi, \pi$ can be decomposed into two $(\mathrm{n} \times \mathrm{r})$ matrices $\alpha$ and $\beta$, such that $\pi=\alpha \beta^{\prime}$ where $\beta^{\prime} z_{t}$ is stationary. Here, $\alpha$ is the error correction term and measures the speed of adjustment in $\Delta z_{t}, \beta$ contains $r$ distinct co-integrating vectors, that is, the co-integrating relationship between nonstationary variables. Johansen (1988) uses the reduced rank regression procedure to estimate the $\alpha$ - and $\beta$-matrices and the trace test statistic is used to test the null hypothesis of, at most, $r$ co-integrating vectors against the alternative that it is greater than $r$.

If co-integration is established among the series, then impulse response analysis (Lutkepohl, 1993, pp. 43-56) can be used to obtain additional information about the dynamic interrelationships among the variables. The impulse response functions trace the effects of a single standard deviation shock to each of the variables in the system over specific time horizons. They are generated under the assumption that the $\pi$-matrix is of the rank determined by the trace statistic and are orthogonalized to account for contemporaneous correlation between equations (Mushtaq \& Dawson, 2002).

\section{Empirical Results}

Table- 1 presents the results of tests of the data series in logarithms for the unit root using the ADF test both with and without a linear trend. In the nontrended model, the absolute values of the ADF statistics for LRWP, LRMS, LY, LTO, and LRER are well below the 95 percent critical value of the test statistics, and hence the null hypothesis of the unit root for these variables is accepted. This shows that the given time series are nonstationary in their level form whereas LDP is a stationary series. In the trended model, the absolute values of the ADF statistics for our five variables LRWP, LRMS, LY, LTO, and LRER are again below the 95 percent critical value of the test statistics, and hence our variables except LDP are nonstationary (Table-1).

In order to test the significance of the trend in the time series, we use the $\tau_{\beta \tau}$ test, in which the null hypothesis is that the variables have no trend against the alternative that the variables have a significant trend. Under this test, the null of no trend is accepted for all the series except for LDP where the trend appears to be significant. These results direct us toward the more powerful $\Phi_{3}$-test. The null hypothesis in the $\Phi_{3}$-test is 
that the variables have a unit root with no trend against the alternative hypothesis that the variables are trend-stationary. Under this test, we cannot reject the null of a unit root and no trend for all the series except for LDP, which appears to be a trend-stationary series. On the basis of all these test results, we conclude that all our data series are nonstationary, i.e., $\mathrm{I}(1)^{5}$ except for LDP, which is a stationary series, i.e., $\mathrm{I}(0){ }^{6}$

Table-1: ADF Unit Root Test Results

\begin{tabular}{lccrrc}
\hline Variables & $\begin{array}{c}\text { Non Trended } \\
\text { Model }\end{array}$ & $\begin{array}{c}\text { Trended } \\
\text { Model }\end{array}$ & $\boldsymbol{\tau}_{\boldsymbol{\beta} \boldsymbol{\tau}}$ & $\boldsymbol{\Phi}_{3}$ & Conclusion \\
\hline LRWP & -1.96 & -2.15 & 1.45 & 3.08 & I (1) \\
LRMS & -2.82 & -1.38 & 1.03 & 4.51 & I (1) \\
LY & -0.77 & -2.43 & 2.33 & 3.04 & I (1) \\
LDP & $-4.76^{*}$ & $-6.21^{*}$ & $3.12^{*}$ & $19.30^{*}$ & I (0) \\
LTO & -1.79 & -1.64 & -1.87 & 3.34 & I (1) \\
LRER & -0.82 & -3.52 & 2.59 & 6.81 & I (1) \\
Critical values & -2.97 & -3.59 & 2.85 & 7.24 & \\
\hline
\end{tabular}

Notes: * Represents significant values.

Critical values (95 percent confidence level) are taken from Fuller (1976, pp. 373). $\mathrm{I}(1)$ = nonstationary and $\mathrm{I}(0)=$ stationary.

After testing for the unit root, the next step is to test for cointegration. The unit root results indicate that the LDP series is I(0), i.e., stationary. Although this $\mathrm{I}(0)$ series cannot interpret the long-run relationship between I(1) variables, it can explain their short-run behavior and is therefore allowed to enter the unrestricted vector autoregressive (VAR) model as an exogenous variable. Johansen's procedure is applied to test the co-integration between the respective variables. The first step is to select the order of the VAR model. We use the LR-statistic, adjusted for small samples (Sims, 1980) to test the null hypothesis that the order of the VAR is $k$ against the alternative that it is 4 , where $k=0,1, \ldots, 4$ and for all cases, $k=1.7$ The second step is to test for the presence and number of co-

\footnotetext{
${ }^{5}$ All the series were made stationary after taking their first-difference; only the TO indicator (LTO) became second-difference stationary.

${ }^{6}$ As per capita food production and population grow at an average annual growth rate of 4.74 and 4.61 percent, respectively, over the given period, gains in food production are eroded by the increase in population. This appears to be an intuitive reason for why per capita food production is stationary.

${ }^{7}$ We also tried the Schwarz Bayesian Criterion (SBC) and Akaike Information Criterion (AIC), which use a lag length of 1 and 4, respectively. To avoid over-parameterization, we chose 1 as the lag length (Pesaran \& Pesaran, 1987).
} 
integration vectors among the series in the model. Table-2 indicates that the first statistical value of the trace test (90.64) is greater than the 95 percent critical value (75.98). We therefore reject the null of no cointegration and accept that there is one co-integrating value. For the remaining three statistical values of the trace test (52.70, 23.70, and 10.37), we fail to reject the null of no co-integration.

Table-2: Co-integration Results for Trace Statistics

\begin{tabular}{lccc}
\hline Null & Alternative & Statistic & Critical Value \\
\hline $\mathrm{r}=0$ & $\mathrm{r}=1$ & 90.64 & 75.98 \\
$\mathrm{r}<=1$ & $\mathrm{r}=2$ & $52.70^{*}$ & 53.48 \\
$\mathrm{r}<=2$ & $\mathrm{r}=3$ & 23.70 & 34.87 \\
$\mathrm{r}<=3$ & $\mathrm{r}=4$ & 10.37 & 20.18 \\
\hline
\end{tabular}

Notes: List of variables included in the co-integrating vector: LRWP, LRMS, LY, LTO, and LRER.

List of $\mathrm{I}(0)$ variables included in the VAR: LDP.

Critical values (95 percent confidence level) are from Pesaran et al. (2000).

* Indicates where the null is not rejected.

In the Johansen model, the parameters in the co-integrating vector can be interpreted as estimates of the long-run co-integrating relationship between variables (Hallam \& Zanoli, 1993). Therefore, the estimated parameter values from these equations (when normalized) for RWPs are long-run elasticities (see Table-3). The coefficients represent estimates of the long-run elasticities of RWPs with respect to the RMS, real per capita domestic income, TO indicator, and RER.

Table-3: Johansen's Normalized Estimates

\begin{tabular}{lcc}
\hline Variable & Long-Run Elasticity & t-Ratio \\
\hline LRWP & 1.00 & 1.00 \\
LRMS & -0.55 & $2.20^{*}$ \\
LY & 0.24 & 0.73 \\
LTO & -0.44 & $-2.75^{*}$ \\
LRER & -0.16 & $-2.00^{*}$ \\
Intercept & 8.36 & 3.41 \\
\hline
\end{tabular}

Note: * Indicates significance at 5 percent.

Contrary to a priori expectations, increases in money supply (LRMS) depress RWPs in Pakistan. This could be due the fact that increases 
in money supply cause inflation, which reduces the effective demand for wheat, thus depressing its price. Real per capita income (LY) has a positive relationship with wheat prices (as per our priori expectations) but shows an insignificant impact. This could be because wheat is a staple food item for a large proportion of the Pakistani population, and most families consume wheat in an almost fixed amount, so growth in incomes enhances food prices but insignificantly. The TO variable (LTO) has a negative impact on RWPs as per our priori expectations. This indicates that greater trade openness in international trade may increase imports, thus decreasing food prices in Pakistan by -0.44 percent in the long run (Kargbo, 2005, estimated -1.619, -1.47, and -7.67 for Cote d'Ivoire, Senegal, and Nigeria, respectively). This result is also in line with the recent experience of the wheat economy in Pakistan: during a wheat shortage, imports stabilize prices by increasing supply in the country. In the case of the exchange rate (LRER), our priori expectation was that it has a positive impact on wheat prices, but the results show that it has a negative impact in the long run. A 1 percent increase in the RER leads to -0.16 percent decrease in wheat prices. This could either be because in most years Pakistan has not been an importer of wheat, or because an overvalued exchange rate was used for agricultural commodities which depreciated exports and thus lowered prices (Kargbo, 2005, also calculated a negative relationship: -0.11 and -0.03 for Cote d'Ivoire and Senegal, respectively).

We estimated an impulse response function to obtain a better understanding of the dynamic interrelationships among the variables, how shocks are transmitted, and how long it takes for shocks to be eliminated. Figure-1 shows that one standard error (SE) shock in the equation for RMS does not have any significant impact on RWPs. 
Figure-1: Generalized Impulse Response(s) to One SE Shock in the Equation for RMS

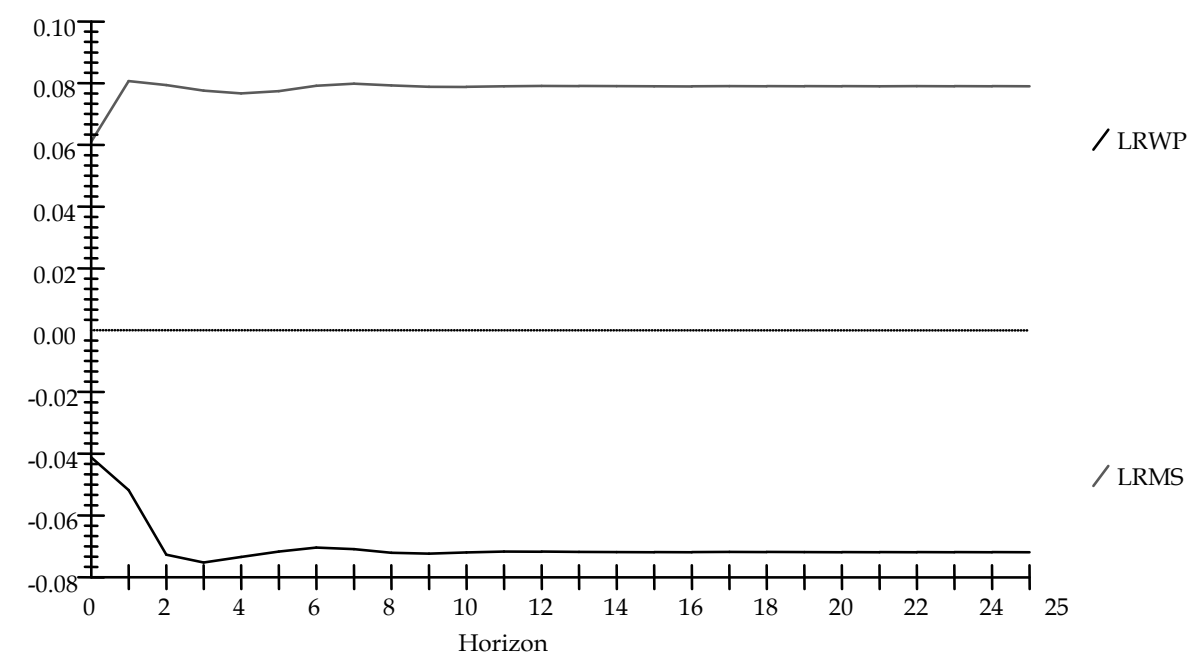

Figure-2 shows that one SE shock in the equation for real per capita income has an impact on RWPs to some extent. The intuitive reason for this might be that an increase in income causes consumers to shift their budgets to luxuries rather than wheat.

Figure-2: Generalized Impulse Response(s) to One SE Shock in the Equation for Real Per Capita Income

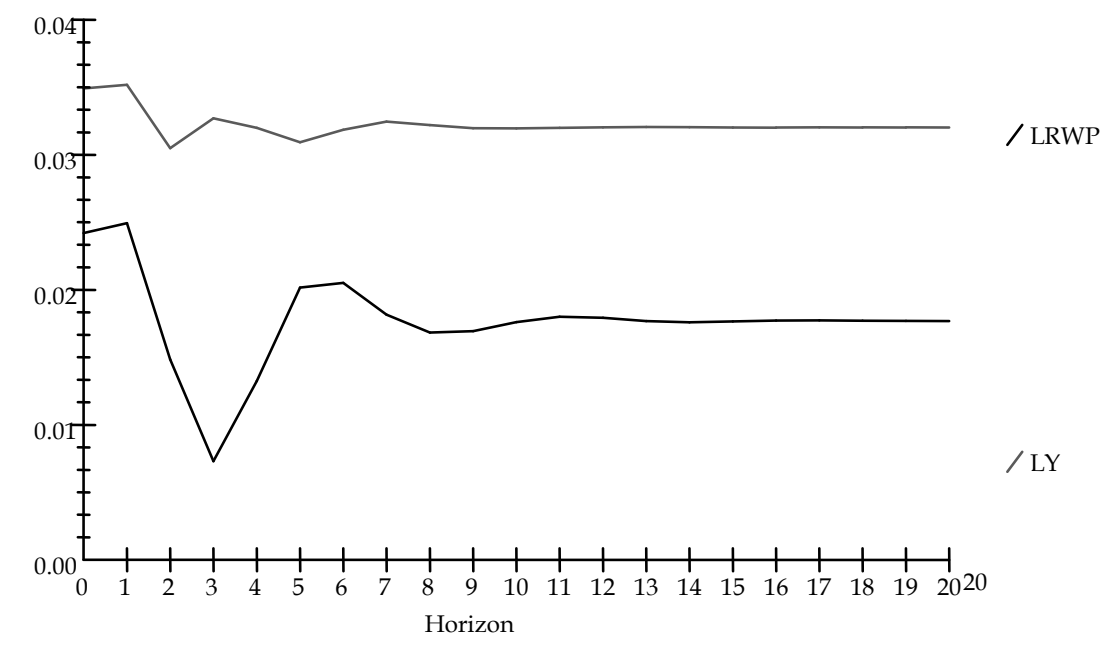

Figure-3 shows that one SE shock in the equation for TO has, as expected, a negative but small effect on RWPs. It takes three to four years for food prices to become stable after a shock in the TO indicator. 
Figure-3: Generalized Impulse Response(s) to One SE Shock in the Equation for TO

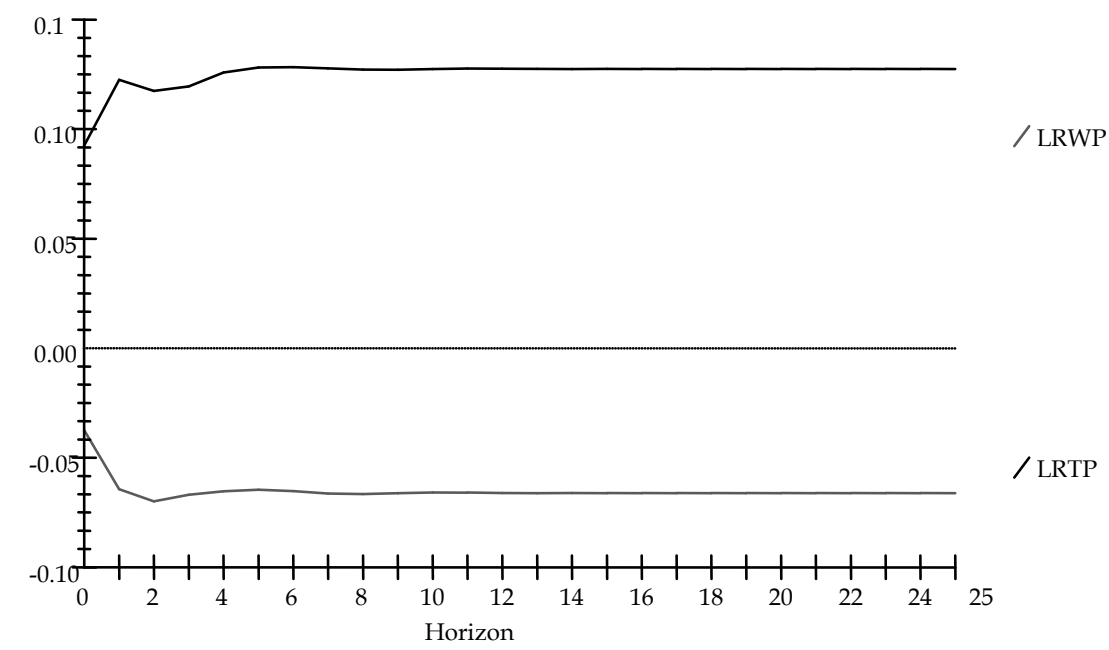

Figure-4 shows that one SE shock in the equation for RER does not cause much change to RWPs and prices look stable. This could be because Pakistan has not been an importer of food items, i.e., wheat, in most years.

Figure-4: Generalized Impulse Response(s) to One SE Shock in the Equation for RER

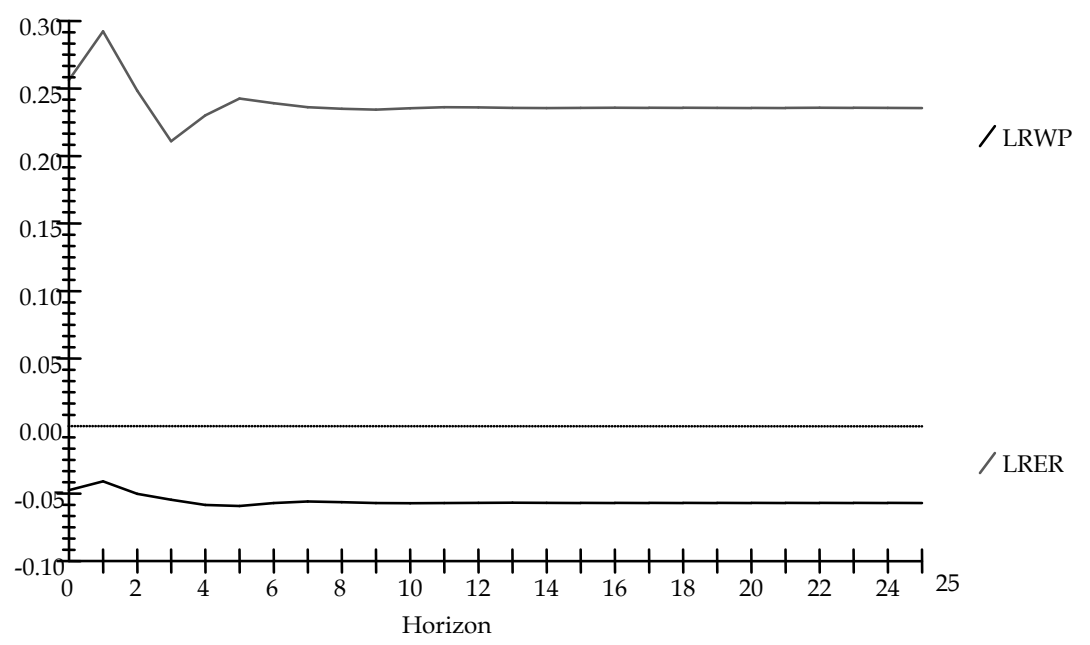

\section{Conclusion and Policy Implications}

We have used Johansen's co-integration approach to evaluate the impact of monetary and macroeconomic factors on RWPs for the period 
1976-2010. All the variables were found to be first-difference stationary, except the TO indicator, which is second-difference stationary, and there is a long-run equilibrium relationship among the concerned variables. The results indicate that RMS, openness of the economy, and RER have had a significant effect on RWPs in the long run. The impulse response function indicated that the TO shock had some impact on wheat prices and that it took three to four years for prices to become stable following the shock.

The findings of the study suggest that the policy thrust should be to increase supply through enhanced domestic production as well as by liberalizing trade, and to stabilize the value of the Pakistani rupee against foreign currencies, especially the US dollar. These policy options could further help to stabilize wheat prices. 


\section{References}

Akbari, A.H., and Rankaduwa, W. (2005). Determinants of Inflation and Feasibility of Inflation Targeting in a Small Emerging Market Economy: The Case of Pakistan. Meeting of the Atlantic Canada Economics Association, Halifax, Nova Scotia.

Asfaha, T.A., and Jooste, A. (2007). The Effect of Monetary Changes on Relative Agricultural Prices. Agrekon, 46, 440-474.

Awokuse, T.O. (2005). Impact of Macroeconomic Policies on Agricultural Prices. Agricultural and Resource Economics Review, 34, 226-237.

Barnett, R.C., Bessler, D.A., and Thompson, R.L. (1983). The Money Supply and Nominal Agricultural Prices. American Journal of Agricultural Economics, 65, 303-307.

Cho, G., Kim, M., and Koo, W.W. (2005). Macro Effects on Agricultural Prices in Different Time Horizons. Meeting of the American Agricultural Economics Association, Providence, Rhode Island.

Dickey, D.A., and Fuller, W.A. (1981). Likelihood Ratio Statistics for Autoregressive Time Series with a Unit Root. Econometrica, 49, 1057-1072.

Dorfman, J.H., and Lastrapes, W.D. (1996). The Dynamic Responses of Crop and Livestock Prices to Money-Supply Shocks: A Bayesian Analysis using Long-Run Identifying Restrictions. American Journal of Agricultural Economics, 78, 530-541.

Ellis, L. (2001). Measuring the Real Exchange Rate: Pitfalls and Practicalities. Research Discussion Paper No. 2001-04, Reserve Bank of Australia.

Fuller, W. A. (1976). Introduction to Statistical Time Series. New York: John Wiley and Sons.

Government of Pakistan (2010). Pakistan Economic Survey, 2009-10. Islamabad: Finance Division, Economic Advisor's Wing.

Greene, W.H. (2000). Econometric Analysis. New Jersey: Prentice-Hall, Inc. 
Hallam, D., and Zanoli, R. (1993). Error Correction Models and Agricultural Supply Response. European Review of Agricultural Economics, 20, 151-166.

Holden, D., and Perman, R. (1994). Unit Roots and Cointegration for the Economist. In Rao, B.B (Ed.), Cointegration for the Applied Economist. New York: St. Martin's Press.

Husain, F., and Mahmood, T. (1998). Causality between Money and Prices: Evidence from Pakistan. Pakistan Development Review, 37, 1155-1161.

Hyder, Z., and Shah, S. (2004). Exchange Rate Pass-Through to Domestic Prices in Pakistan. Working Paper No. 5, Islamabad: State Bank of Pakistan.

Jabara, C.L., and Schwartz, N.E. (1987). Flexible Exchange Rates and Commodity Price Changes: The Case of Japan. American Journal of Agricultural Economics, 69, 580-590.

Johansen, S. (1988). Statistical Analysis of Cointegrating Vectors. Journal of Economic Dynamics and Control, 12, 231-254.

Kaabia, M.B., Gil, J.M., and Shebbi, H.E. (2005). Macroeconomics and Agriculture in Tunisia. 11 $1^{\text {th }}$ Congress of the European Association of Agricultural Economists, Copenhagen, Denmark.

Kargbo, J.M. (2000). Impacts of Monetary and Macroeconomic Factors on Food Prices in Eastern and Southern Africa. Applied Economics, 32, 1373-1389.

Kargbo, J. M. (2005). Impacts of Monetary and Macroeconomic Factors on Food Prices in West Africa. Agrekon, 44, 205-224.

Khan, M. S., and Schimmelpfennig, A. (2006). Inflation in Pakistan: Money or Wheat? (Research Bulletin 2). Islamabad: State Bank of Pakistan.

Khan, A.H., and Qasim, M.A. (1996). Inflation in Pakistan Revisited. Pakistan Development Review, 35, 747-759.

Lapp, J. S., \& Smith, V. H. (1992). Aggregate Sources of Relative Price Variability among Agricultural Commodities. American Journal of Agricultural Economics, 74, 1-9. 
Lutkepohl, H. (1993). Introduction to Multiple Time Series Analysis. $2^{\text {nd }}$ ed. New York: Springer-Verlag.

Mushtaq, K., and Dawson, P. J. (2002). Acreage Response in Pakistan: A Cointegration Approach. Agricultural Economics, 27, 111-121.

Niaz, S. (1995). Pricing of Farm Produce in Pakistan: Objectives, Practices and Experiences. Islamabad: Print Associates International.

Orden, D., and Fackler, P.L. (1989). Identifying Monetary Impacts on Agricultural Prices in VAR Models. American Journal of Agricultural Economics, 71, 495-502.

Pesaran, M.H., and Pesaran, B. (1987). Working with Microfit 4.0: Interactive Econometric Analysis. Oxford University Press.

Pesaran, M. H., Shin, Y., and Smith, R. J. (2000). Structural Analysis of Vector Error Correction Models with Exogenous I(1) Variables. Journal of Econometrics, 97 (2), 293-343.

Qayyum, A. (2006). Money, Inflation, and Growth in Pakistan. Pakistan Development Review, 45, 203-212.

Robertson, J.C., and Orden, D. (1990). Monetary Impacts on Prices in the Short and Long Run: Some Evidence from New Zealand. American Journal of Agricultural Economics, 72, 160-171.

Sephton, P.S. (1992). Modelling the Link between Commodity Prices and Exchange Rates: The Tale of Daily Data. Canadian Journal of Economics (Revue canadienne d'Economique), 25, 156-171.

Sims, C. A. (1980). Macroeconomics and Reality. Econometrica, 48, 1-49.

Taylor, J.S., and Spriggs, J. (1989). Effects of the Monetary MacroEconomy on Canadian Agricultural Prices. Canadian Journal of Economics (Revue canadienne d'Economique), 22, 278-289. 